\title{
WHAT WILL YOU DO AFTER GRADUATED FROM UNIVERSITY? INCREASING CAREER DECISION SELF-EFFICACY THROUGH CAREER COUNSELING
}

\author{
Kusumasari Kartika Hima Darmayanti ${ }^{1^{*}}$, Dimas Teguh Prasetyo ${ }^{1}$, Efan Yudha Winata ${ }^{1}$, \\ Pratiwi Sakti ${ }^{1}$ \\ ${ }^{1}$ Universitas Teknologi Sumbawa, Sumbawa 84371, Indonesia \\ *) E-mail: kusumasarikhd@gmail.com
}

\begin{abstract}
One of the biggest challenges that have to be faced by students of university is deciding on a specific career after graduating from university. The aims of this study are for knowing what students needed (study 1) and for testing whether career counseling can increase CDSE students of the university (study 2). In study 1 , we use qualitative and quantitative approaches. On the other side, study 2 uses Quasi-Experimental within-subject pre and post-tests designed to monitor the role of career counseling on students. Study 2 involves $(N=15)$ students CDMSES-SF is adopted in Bahasa and Culture. Using the Wilcoxon test on SPSS 24, we intend to know the significance of changes in students' CDSE. The results from study 1 are what needed on career counseling is materials concerning on grooming and writing curriculum (54.8\% of 31 students), planning for facing the environment where they work (51.6\% of 31 students), and tips and strategies to obtain a scholarship for the master program (54.8\% of 31 students). Then, results of study 2 indicate there is a significant change of gathering occupational information $(Z=-2.194 ; p<.05)$ and making plans for the future $(Z=-$ 2.204; $p<.05)$ after career counseling. From this research, future career counseling concerns gathering occupational information and making plans for the future.
\end{abstract}

Keywords: career counseling, CDSE, graduation, university students

\section{Apa yang Akan Anda Lakukan Setelah Lulus dari Universitas? Meningkatkan Career Decision Self-Efficacy Melalui Konseling Karier}

\begin{abstract}
Abstrak
Salah satu tantangan terbesar yang harus dihadapi oleh mahasiswa adalah membuat keputusan tentang karier tertentu setelah lulus dari universitas. Tujuan dari penelitian ini adalah untuk mengetahui apa yang dibutuhkan siswa (studi 1) dan untuk menguji apakah konseling karier dapat meningkatkan siswa CDSE dari universitas (studi 2). Dalam studi 1, kami menggunakan pendekatan kualitatif dan kuantitatif. Di sisi lain, Studi 2 menggunakan Kuasi-Eksperimental dengan pra dan pasca tes subjek yang dirancang untuk memantau peran konseling karier pada siswa. Studi 2 melibatkan $(N=15)$ siswa CDMSES-SF diadopsi dalam Bahasa dan Budaya. Menggunakan uji Wilcoxon pada SPSS 24, kami bermaksud untuk mengetahui pentingnya perubahan pada CDSE siswa. Hasil dari studi 1 adalah apa yang diperlukan pada konseling karier adalah materi mengenai kurikulum perawatan dan menulis $(54,8 \%$ dari 31 siswa), perencanaan untuk menghadapi lingkungan tempat mereka bekerja ( $51,6 \%$ dari 31 siswa), dan tips serta strategi untuk memperoleh beasiswa untuk program master ( $54,8 \%$ dari 31 siswa). Kemudian, hasil penelitian 2 menunjukkan ada perubahan yang signifikan dalam mengumpulkan informasi pekerjaan $(Z=-2,194 ; p<0,05)$ dan membuat rencana untuk masa depan $(Z=-2,204 ; p<0,05)$ setelah konseling karier. Dari penelitian ini, konseling karier masa depan berkaitan dengan gathering occupational information and making plans for the future.
\end{abstract}

Kata kunci: CDSE, konseling karier, mahasiswa, wisuda

\section{INTRODUCTION}

Students who have just completed their undergraduate education will be faced with several choices. Among them is continuing education at the master's level, getting married, 
and working. Those who decide to continue their master's education are faced with future career plans. Thus, students who have completed their undergraduate programs are in a transition between the academic climate and the work climate.

On the other hand, Tolentino, Garcia, Lu, Restubog, Bordia, and Plewa (2014) state that the effect of the recovery of the market economy is the decline in labor so that some people experience a career pressure. Career pressure, one of which, causes students who have graduated difficulty in applying careers that are by their wishes. Furthermore, Kahn (2010) explained that students who have just graduated and developed careers often feel that the careers they are in are not by their talents, interests, and passions. Also, Kahn (2010) also mentioned that they were unemployed after graduation.

\section{Career Decision Self-efficacy}

The situation mentioned above occurs as a result of the condition of the Career Decision Self-Efficacy (CDSE) of students. Taylor and Betz (1983) explain the CDSE with an individual's belief in his ability that they can complete tasks related to career decisions. Individuals with confidence in their abilities seem to have no doubts and experience obstacles in deciding a career. Likewise, if individuals have doubts or difficulties in deciding on a career indicate that their CDSE is low, so they have difficulty in making decisions related to future careers, areas of study related to future careers, and activities they wish to pursue after completing education.

The theoretical foundation of the CDSE is based on the Social Cognitive Career Theory (SCCT; Lent, Brown, \& Hackett, 1994) which refers to individual learning that focuses on self-efficacy and expectations (Choi et al., 2011). Both of these things that lead individuals to how they determine their careers (Choi et al., 2011; Lent et al., 2005). Furthermore, Hackett and Betz (1981) mention one domain of career self-efficacy that describes strategies in the decision-making process. Thus, Taylor and Betz (1983) suggested the domain of selfefficacy in the sphere of behavior in career decision making that is of interest.

Furthermore, Taylor and Betz (1983) suggested that CDSE consists of five dimensions to represent CDSE. CDSE consists of five dimensions, namely: Accurate self-appraisal relating to how individuals understand their interests and passions, gathering occupational information where individuals are encouraged to seek information from several sources related to the availability of career opportunities, goal selection related to individual strategies to realize their goals, making plans for the future relates to the mapping of planning related to the steps to be taken relating to a career that has been decided, and problem-solving in which individuals have a way to overcome problems that might be encountered when choosing, establishing, and conducting the recruitment process.

SSCT (Lent et al., 1994) is included in the scope of career development, developed by Super (1980), i.e. career management processes that are last for a lifetime (Super, 1980). In addition to the SCCT, Career Construction Theory (CCT; Savickas, 2002) reports that CDSE plays an important role in the career decision process (Creed, Patton, and Prideaux, 2007). CCT in vocational development emphasizes more on career adaptability than career maturity (Savickas, 2002). Savickas (2002) defines career adaptability as the readiness of individuals in coping related to some anticipation of career development tasks. In career adaptability, Savickas (2002) mentions four indicators in the adaptation process, namely: (1) Concerninghow individuals focus on preparing for their future careers; (2) Control-the ability of individuals to direct themselves towards careers that are by their abilities and interests; (3) Curiosity-related to how individuals see career opportunities in the future with their abilities; and (4) Confidence-individuals' capability to face the obstacles encountered when developing a career. 
The research of Shin, Lee, and Seo (2018) makes the CDSE as a mediator of the Implicit Association Test (IAT; i.e. role of gender in society; Greenwald, McGhee, \& Schwartz, 1998) and career adaptability. In their research, Shin et al. (2018) reported that CDSE contributes to career adaptability. Likewise, with Douglass and Duffy's (2015) research, they found a significant positive relationship between the four components of career adaptability with CDSE. This indicates an increase in the unit of concern, control, curiosity, and confidence will be followed by an increase in the CDSE unit (Douglass \& Duffy, 2015).

Furthermore, Houle (2011) reports that CDSE is also influenced by career maturity. Career maturity, based on Super (1990), is one of the constructs that also plays a role in career development. For the definition of career maturity, Crites (1973) defines it as an individuals' readiness to decide on a career against several career choices that have been previously considered. Also in 1973, Crites developed a career maturity measurement tool called the Career Maturity Inventory (CMl; Crites, 1973), which was used to determine the individuals' decisiveness, involvement, independence, orientation, and compromise. Prideaux and Creed (2001) explain that the measuring instrument is also used to measure self-appraisal, occupational information, goal selection, planning, and problem-solving. Also, in 1974, Crites detailed several facets on career maturity, namely: (1) Consistency-related to how often individuals maintain their career choices; (2) Realism-how the chosen career is a suitability with abilities and interests; (3) Competencies-the ability of individuals to make plans, solve problems, set goals, obtain information, and evaluate themselves against the desired career; and (4) Attitudes-related to the career selection process, work orientation, independence in deciding on a career, and understanding several factors involved in the career selection process.

On the other hand, Taylor and Betz (1983) also mentioned that CDSE consists of five dimensions namely accurate self-appraisal, gathering occupational information, goal selection, making plans for the future, and problem-solving. When compared based on CMI, the dimensions of each career maturity and CDSE overlap. Meanwhile, when comparing career maturity with CDSE based on several points submitted by Crites (1974), the overlapping side is found in the five dimensions of CDSE with competencies.

\section{Career counseling}

Career, based on what is said by Super (1951), by the interests of each individual. This is because individual careers can increase individual self-esteem if the specified career raises satisfaction (Super, 1951). The chance for a career to be determined is related to their interests, abilities, and environment where they are (Super, 1951). Thus, Savickas (2005) adds that the career selection process lasts a lifetime because it involves individuals to adjust themselves to the situation where and when they are.

On the other hand, Dawis (2005) said that career counseling is a process that helps clients (e.g. students, parents, a retired employee, etc.) to determine their future careers so that they feel the satisfaction of choosing the career they want. Savickas (2005) added that career counseling aims to improve the ability of individuals to choose, determine, and decide on a career so that individuals have more confidence in deciding on a career.

In the transition between preparing for graduation and facing the world of work, the Faculty of Psychology, Sumbawa University of Technology facilitates several students to be better prepared to face the world of work. Not only the world of work but they are also faced with the desire and need to continue their master's degree studies. In deciding to continue their own master's program studies, they also must prepare funding, study program options, and universities. 
Regarding funding during the study program, students are faced with choices. Those with a background of above-average socioeconomic status do not overly question the issue of tuition financing and some needs during the master's study program. On the other hand, for those with a background of below-average social and economic status, they will consider some scholarship information. Not only scholarship information, because the funding of graduate programs is very competitive, they are also faced with implementing several strategies so that the values that exist within themselves are in line with the values expected by the scholarship. Also, in Indonesia itself, there are several institutions providing scholarships for master programs, both from the Indonesian government itself, as well as from foreign governments who have worked closely with the Indonesian government.

Some students want to deepen the study of linear psychology with the study programs they are taking in undergraduate studies. Meanwhile, the field of study in psychology masters itself has several options, namely: The psychological profession master program, the science psychology master program, and the applied psychology program. Then, for students who want to continue their studies with a background program that is not linear with the study program when pursuing an undergraduate program, they should adjust the choice of the nonlinear study program to their future career and their interests while undergoing lectures.

For students who wish to continue their studies, they are also faced with several choices whether they will continue their studies at campuses in the country or continue their studies abroad. If they continue their studies at campuses in Indonesia, they will determine the choice of several campuses in Indonesia (e.g. public campus or private campus). Meanwhile, if they want to continue their studies abroad, they must first determine their destination country then their destination campus. The determination of the campus made them confused.

For 3.5, 4 years, or more they are accustomed to the academic world, it is important for merit is important for them to know the world of work. Likewise, career counseling also emphasizes the challenges faced by millennials and generation $\mathrm{Z}$ in preparing their careers. Lifelong careers require them to know more about how they adapt to work environments and coworkers which incidentally come from cultural backgrounds, languages, socioeconomic status, education, and several different social constructions.

In career counseling, the materials presented are (1) Techniques for making curriculum vitae and grooming, (2) Information, tips and tricks for master scholarships, and (3) Selfpreparation in the world of work. This material is based on a short survey based on several things needed by students after graduation from the Faculty of Psychology, Sumbawa University of Technology; (1) Techniques for making curriculum vitae and grooming. The technique of making curriculum vitae is by the indicators of career adaptability (i.e. confidence). In career adaptability, Savickas (2005) states that this confidence is seen when individuals can overcome several challenges and problems in career selection, while the technique of creating curriculum vitae is a vital part of applying for a job. In the employee selection process, the first stage is usually in the form of curriculum vitae selection, so the ability needed is to create attractive curriculum vitae to pass the first stage selection. About career maturity, the creation of curriculum vitae represents one of the facets in career maturity, namely competencies, which is making curriculum vitae related to how individuals prepare to apply for jobs; (2) Information, tips, and tricks for master scholarships. Regarding career maturity, this material is very closely related to the four facets of career maturity. This material is also by the four indicators of career adaptability; (3) Self-preparation in the world of work. This third material is by career adaptability, which according to Savickas (2005) individuals will find satisfaction with their careers when the career is by themselves and the environment. Their preparation in this digital era also indicates that the presence of career counseling contributes to making them more confident and ready to take part in the world of work. 
Several studies have found the significance of the role of career counseling to improve CDSE. Park, Rie, Kim, and Park (2018) report their research on the role of career counseling to improve Future Time Perspective and CDSE. For CDSE, they report that career counseling contributes to improving CDSE. On the other hand, Rochat and Armengol (2018) report that adjusting to the characteristics of Western society, they construct career counseling using video games. Although they do not calculate the increase in participants' self-efficacy related to career development, career counseling using video games can find out the participants' career interests and increase the participants' enthusiasm for engaging in the professional world of work (Rochat \& Armengol, 2018). Furthermore, the results of a literature study conducted by Bezanson, Hopkins, and Neault (2016) found that practitioners of career counseling and career development are needed to improve the ability of individuals to choose careers to maintain the economic stability of Canadian society.

As a tertiary institution and seeing the phenomenon of career stress, the Faculty of Psychology has the responsibility to provide career counseling. Career counseling is intended to improve student CDSE. Career counseling is given to prospective graduates who want to become alumni. They are faced with a transition period between completing the lecture process and deciding on a career. A career counseling facility is the first activity held at the Faculty of Psychology. Career counseling is carried out in two processes, the first is students filling out the survey distribution related to the material they need in career counseling, and the second is the implementation of career counseling itself.

Previously, several studies showed the increasing significance of student CDSEs with career counseling (Foltz \& Luzzo, 1998; Wang, Zhang, \& Shao, 2010; Jeong \& Kim, 2011; Miles \& Naido, 2016; Glessner, Rockinson-Szapkiw, \& Lopez, 2017; Falco \& Summer, 2017; Lam \& Santos, 2018). Meanwhile, for Indonesia, the study of Pambudi, Mulawarman, and Japar (2019) found that CDSE can be improved by modeling techniques, which are a series of career interventions in the form of psychoeducational groups. In the process of psychoeducational groups, Pambudi et al. (2019) explained some of the agendas carried out, namely sharing sessions, practical abilities, and interpersonal communication processes. With the increase in CDSE, it will later lead to aspects of career planning desired by students (Pambudi et al., 2019). Based on the explanation, this study aims to find out what material is needed by students in career counseling programs and to test whether career counseling programs improve students' CDSE.

\section{METHODOLOGY}

\section{Study 1}

In this section, Study 1 is a baseline study conducted as a basis for making interventions. This stage the author uses qualitative and quantitative approaches. The qualitative approach was carried out using the unstructured interview method for two lecturers. Interviews were conducted to explore the vision and mission, resources, and programs of the Faculty, especially in terms of career counseling and services for prospective graduates who will also become an alumna.

After extracting information from two lecturers, then We surveyed the participants. Participants in Study 1 are students who have graduated and will attend the graduation ceremony. This survey was conducted starting from 14-16 September 2019 through filling out the google form platform. Participants were given two main questions. First 'what do you need right now for your post-graduate career?'. While the second question is 'what are your plans after graduating from college?'. Both of these questions, participants can choose some closed answers that have been provided based on the results of interviews with previous lecturers. The data was taken with the saturated sample technique because the sample 
consisted of only 40 prospective graduates. Of the 40 target participants, only 31 participants were willing to fill out this survey.

\section{Study 2}

Study 2 is an intervention study. This study was conducted one week after the implementation of the baseline study (study 1). The author uses a quasi-experimental approach within the subject pre and post-test design. Provision of manipulation in this study in the form of career counseling. Career counseling referred to in this study is a one-day workshop for 7 hours in an auditorium. Participants fill out the pre-test before the workshop begins and fill in the post-test after the workshop is finished. The pre and post-test analysis in this study use the non-parametric Wilcoxon test approach to test scores of the same subject in a group of two different circumstances (before and after manipulation). Both the pre-test and post-test contained a 25-question CDMSES-SF (Career Decision-Making Self-Efficacy Short-Form; Taylor \& Betz, 1983). The CDSE scale is assessed as a multidimensional scale consisting of five dimensions, namely accurate self-appraisal, gathering occupation information, goal selection, making plans for the future, and problem-solving. This CDMSESSF is 6 -points Likert ( $1=$ very unsure; 6 = very sure).

The CDMSES-SF was adopted from a previous study by Salim and Darmayanti (n.d.). This scale has been validated with a validity score of .25 and has a reliability of $(a=.899)$. The sample items that represent each of the CDSE dimensions are as follows:

Table 1 Example of Item

\begin{tabular}{ll}
\hline \multicolumn{1}{c}{ Dimensions of CDSE } & \multicolumn{1}{c}{ Item } \\
\hline $\begin{array}{l}\text { Accurate self-appraisal } \\
\text { Gathering occupational information }\end{array}$ & $\begin{array}{l}\text { Accurately assessing my abilities } \\
\text { Looking for information about jobs that are } \\
\text { compliant with my interests (from family, friends, } \\
\text { idols, etc.) } \\
\text { Choose a major for further study from several } \\
\text { majors that I have considered. }\end{array}$ \\
Making plans for the future & $\begin{array}{l}\text { Make plans to achieve my goals in } 5 \text { years which } \\
\text { will come. } \\
\text { Determine the steps to be taken when facing } \\
\text { Droblem solving }\end{array}$ \\
academic problems in the department that I am \\
select.
\end{tabular}

Participants in this study were taken purposively, namely students who will graduate in September 2019. Therefore, all 40 graduate students were made as participants in this study. However, of the 40 participants who will pass September 2019, only 26 participants can attend this career counseling. While from 26 participants who attended, only 15 participants were willing to take pre and post-test in this study.

According to table 2, participants who took part in this career counseling were given three main materials namely (1) Techniques for making curriculum vitae and grooming, (2) Information, tips and tricks for master scholarships, and (3) Self-preparation in the world of work. The three materials were obtained based on a survey of student needs previously in Study I. The three materials were delivered by lecturers who have competence in their fields. The three speakers used the presentation and question and answer method with the participants during the workshop. All participants in this study were given compensation for lunch and souvenirs at the end of the workshop. 
Darmayanti, et al., JKKP 7 (1) (2020) 26-37

Table 2 Rundown for Career Counselling

\begin{tabular}{|c|c|c|}
\hline Part & Time & Activity \\
\hline 1 & $09.00-10.00$ & $\begin{array}{l}\text { Opening speech from Dean of Faculty of Psychology, } \\
\text { general introduction and pretest }\end{array}$ \\
\hline 2 & $09.30-10.30$ & Techniques for making curriculum vitae, and grooming \\
\hline 3 & $10.30-11.00$ & Break time \\
\hline 4 & $11.00-12.00$ & Information, tips, and tricks for master scholarships \\
\hline 5 & $12.00-13.00$ & Lunchtime \\
\hline 6 & $13.00-14.00$ & Self-preparation in the world of work \\
\hline 7 & $14.00-14.30$ & Discussion time \\
\hline 8 & $14.30-15.00$ & Post-test and closing \\
\hline
\end{tabular}

\section{RESULTS AND DISCUSSION}

\section{Study 1}

Based on need analysis from a survey of 31 participants, two important points can be identified as the basis for intervention. First, the current needs as a career preparation after graduating from college. The results of the three highest choices in the survey showed that $54.8 \%$ of participants needed the technique of making curriculum vitae and grooming. On the other hand, there were $54.8 \%$ of participants who needed information, tips, and tricks on master scholarships. Preparation in the world of work was chosen by $51.6 \%$ of participants. While the second is the participant's plan after graduating from college. The results of the three highest choices in the survey showed that $80.6 \%$ of participants planned to work in the company, $48.4 \%$ planned to continue their master studies, and $38.7 \%$ planned to open their businesses. Therefore, the faculty of psychology must provide an activity to prove their needs before they graduate.

\section{Study 2}

Based on the results of the Wilcoxon test analysis using IBM SPSS v.24 on the pre and post-test scores, it was found that there was no significant change in the overall mean total CDSE score $(p>.05, p=.95)$. Meanwhile, testing was also carried out on the five dimensions of CDSE. The results show that only the gathering occupational information dimension and making plans for the future have a change in the mean score $(p<.05)$. While the other three dimensions, namely goal selection, accurate self-appraisal, and problem-solving, there were no significant changes in the mean pre and post-test scores. The complete results can be seen in the following table:

Table 3. Pre-Test and Post-Test

\begin{tabular}{lllcccc}
\hline No & Score & \multicolumn{1}{c}{ Dimension } & Mean & SD & Z & p \\
\hline 1 & Pretest & Accurate self-appraisal & 21.53 & 4.340 & -1.792 & .073 \\
& Posttest & & 23.33 & 4.169 & & \\
2 & Pretest & Gathering occupational & 22.80 & 4.411 & -2.194 & .028 \\
& Posttest & information & 24.73 & 3.807 & & \\
3 & Pretest & Goal selection & 22.20 & 4.346 & -.594 & .553 \\
& Posttest & & 22.93 & 4.350 & & \\
4 & Pretest & Making plans for the future & 21.53 & 4.518 & -2.204 & .027 \\
& Posttest & & 23.67 & 3.940 & & \\
5 & Pretest & Problem solving & 20.87 & 5.249 & -1.174 & .240 \\
& Posttest & & 22.60 & 5.068 & & \\
\hline
\end{tabular}


Based on the results of the initial study conducted there are needs and desires of participants, including the technique of making curriculum vitae and grooming, then after graduating from college wish to plan to work in the company, continue master studies and open their businesses. The participants' needs and desires form the basis of an intervention in the form of career counseling on a CDMSES-SF.

The results of the career counseling carried out showed that overall there was no significant change in the mean total CDSE score. This shows that the self-efficacy of the participants is not so high that participants tend to have difficulty in making decisions about their careers.

The results of this study are not in line with the findings of a study conducted by Wang et al. (2010), Glessner et al. (2017), and Lam and Santos (2018). Towards career planning and deciding on a career that suits interests, Wang et al. (2010) found that the group training they implemented for students' college proved to be significant in increasing their CDSE. As for some of the series of activities contained in the group, training is knowing the achievements, an explanation of seeking the desired career information, understanding passion, determining career goals and planning, and applying for a job (Wang et al., 2010), which all series the activity is related to the five dimensions of the CDSE.

Meanwhile, the results of tests conducted on the CDSE dimension indicate that two dimensions show significant results, including gathering occupational information and making plans for the future. This shows that participants have a high self-efficacy can facilitate participants in finding information from several sources related to the availability of career opportunities, and be able to do mapping, planning related to the steps to be taken related to a career that has been decided.

Gathering occupational information can be obtained through online and offline networks, by utilizing the use of the internet or discussing careers with practitioners, and information obtained through relationships (Taylor \& Betz, 1983). Students who have enough information about careers that are by their interests, abilities, and lifestyle, are components of the ability to decide on a career.

Making plans for the future relates to preparing for making a curriculum vitae or preparing for the interview selection stage (Taylor \& Betz, 1983). Students who make career decisions make preparations and make plans. Planning and preparation are related to matters relating to the process of applying for a job. Not only making a good curriculum vitae and preparing for interviews and other career selection stages but also preparing clothes and professional photographs to pass the selection stage.

Taylor and Betz (1983) explained that the five dimensions of CDSE (i.e. accurate selfappraisal, gathering occupational information, goal selection, making plans for the future, and problem-solving) are components found in one of the facets in career maturity (i.e. Competence; Crites \& Savickas, 1996). Crites and Savickas (1996) developed the Career Maturity Inventory (CMI or VDI: Vocational Development Inventory) measurement tool that facet competence in career maturity consists of self-appraisal, occupational information, goal selection, planning, and problem-solving.

The significance of the increase in post-test in gathering occupational information and making plans for the future indicates that in terms of career maturity, students of the Faculty of Psychology at the Sumbawa University of Technology have improved strategies in finding information related information to continue master studies and improvement in planning for future careers they. For facet competencies in career maturity, because there is no increase in CDSE, overall and three dimensions (self-appraisal, goal selection, and problems) in detail per subscale, they do not indicate an increase in CDSE and career maturity.

When referring to career adaptability, Savickas (2005) explains one dimension of career adaptability, which is concerned. Making plans for the future (Taylor \& Betz, 1983) is relevant 
to the concept of concern (Savickas, 2005) which, according to Super (1980), is planfulness. This planfulness is a skill possessed by individuals which can be seen from the increasing optimism about the concerned related to their future either as a master's program student or working by the career specifications they are interested in (Savickas, 2005). According to Savickas (2005), career counseling in the future is oriented to several activities and tasks related to careers.

For gathering occupational information (Taylor \& Betz, 1983), Savickas (2005) mentions one dimension of career adaptability, called career curiosity. Career curiosity refers to an individual's curiosity about a career (i.e. whether the desired career suits them) that moves them to explore several careers for their future. This relates to how individuals seek and obtain as much information as possible about aspects of the world of work to suit themselves.

Based on the material presented in career counseling which includes (1) Techniques for making curriculum vitae and grooming, (2) information, tips and tricks for master scholarships, and (3) self-preparation in the world of work, all three materials are significantly influencing the gathering of occupational information and making plans for the future students. Occupational information gathering refers to the process of finding information that refers to students' interests, abilities, and passions, all of which are related to career planning that suits them (Taylor \& Betz, 1983). Gathering occupational information on career counseling is contained in the career counseling material information, tips, and tricks for master scholarships. Meanwhile, for the two materials in career counseling, it refers to the CDSE dimension making plans for the future. Planning for applying the job lies in the material on how to make curriculum vitae.

Falco and Summers (2017) state that self-efficacy in the field of study contributes to students' careers. The stronger the students' self-efficacy, the easier it is for students to decide on a career (Falco \& Summers, 2017). Falco and Summers (2017) research indicate that the career interventions they provide are significant in increasing participant CDSE. In that study, Falco and Summers (2017) emphasize aspects of career interventions that emphasize self-efficacy in the fields of Science, Technology, Engineering, and Mathematics (STEM), which then with strong self-efficacy in the STEM can improve self-efficacy student in deciding careers in the STEM field. As research conducted by Falco and Summers (2017), future research can emphasize aspects of career counseling by emphasizing aspects of student self-efficacy in the field of psychology studies. Thus, students are expected to be able to improve self-efficacy which will increase self-efficacy when deciding on a career that is in line with the educational background of undergraduate psychology.

To improve the overall dimensions of CDSE and CDSE itself, career counseling also needs to pay attention to material that refers to accurate self-appraisal, goal selection, and problem-solving. Because the purpose of career counseling is to improve CDSE, the material and activities in career counseling refer to the dimensions of CDSE (Taylor \& Betz, 1983; Wang et al., 2010) and SCCT (Lent et al., 1994; Wang et al., 2010).

\section{CONCLUSION AND SUGGESTION}

What needed on career counseling is materials concerning grooming and writing curriculum (54.8\% of 31 students), planning for facing the environment where they work (51.6\% of 31 students), and tips and strategies to obtain a scholarship for the master program (54.8\% of 31 students). Also, there is no implication of career counseling on change of CDSE's total score, but there is a significant change in gathering occupational information and making plans for the future. The output and outcome of the intervention program are the keys to successfully holding career counseling at university. Also, career counseling is important for increasing students' CDSE, especially to increase gathering occupation 
information and making plans for the future. Further, instead of concerning the urgency of career counseling, further career counseling program emphasizes the materials also consisting of dimensions from CDSE, i.e. accurate self-appraisal, gathering occupational information, goal selection, making plans for the future, and problem-solving.

\section{REFERENCES}

Bezanson, L., Hopkins, S., \& Neault, R. A. (2016). Career guidance and counselling in Canada: Still changing after all these years. Canadian Journal of Counseling and Psychotherapy, 50(3). Retrieved from https://cjc-rcc.ucalgary.ca/article/view/61123.

Choi, B. Y., Park, H., Yang, E., Lee, S. K., Lee, Y., \& Lee, S. M. (2012). Understanding Career Decision Self-efficacy: A Meta-Analytic Approach. Journal of Career Development, 39(5), 443-460. Retrieved from http://journals.sagepub.com/doi/10.1177/08 94845311398042.

Creed, P. A., Patton, W., \& Prideaux, L. A. (2007). Predicting change over time in career planning and career exploration for high school students. Journal of adolescence, 30(3), 377-392. https://doi.org/10.1016/j.adolescence.2006.04.003.

Crites, J. O. (1973). Career maturity inventory. New York: McGraw-Hill.

Crites, J. O. (1974). Major Contribution Career Counseling: A Review of Major Approaches. The Counseling 3-23. https://doi.org/10.1177/001100007400400302.

Crites, J. O., \& Savickas, M. L. (1996). Revision of the career maturity inventory. Journal of career assessment, 4(2), 131-138. https://doi.org/10.1177/106907279600400202.

Dawis, R. V. (2005). The Minnesota theory of work adjustment. In S. D. Brown \& R. W. Lent (Eds.), Career development and counseling: Putting theory and research to work (3-23). New Jersey: John Wiley \& Sons, Inc.

Douglass, R. P., \& Duffy, R. D. (2015). Calling and career adaptability among undergraduate students. Journal of Vocational Behavior, 86, 58-65. https://doi.org/10.1016/j.jvb.2014.11.003.

Falco, L. D., \& Summers, J. J. (2017). Improving career decision self-efficacy and STEM selfefficacy in high school girls: Evaluation of an intervention. Journal of career development, 46(1), 62-76. https://doi.org/10.1177/0894845317721651.

Foltz, B. M., \& Luzzo, D. A. (1998). Increasing the career decision-making self-efficacy of nontraditional college students. Journal of college counseling, 1(1), 35-44. https://doi.org/10.1002/j.2161-1882.1998.tb00122.x.

Glessner, K., Rockinson-Szapkiw, A. J., \& Lopez, M. L. (2017). “Yes, I Can”: Testing an Intervention to Increase Middle School Students' College and Career Self-Efficacy. The Career Development Quarterly, 65(4), 315-325. https://doi.org/10.1002/cdq.12110.

Greenwald, A. G., McGhee, D. E., \& Schwartz, J. L. (1998). Measuring individual differences in implicit cognition: the implicit association test. Journal of personality and social psychology, 74(6), 1464.

Hackett, G., \& Betz, N. E. (1981). A self-efficacy approach to the career development of women. Journal of Vocational Behavior, 18, 326-339. doi:10.1016/0001-8791(81)900191.

Houle, J. (2010). An examination of the relationship between athletic identity and career maturity in student-athletes. Retrieved from http://etd.auburn.edu/handle/10415/2443. 
Jeong, I. J., \& Kim, S. J. (2011). The effect of career group counseling program using cinema on self-identity and career decision-making self-efficacy of adolescent on probation. $J$ Korean Soc Sch Health, 24(2), 164-172. Retrieved from http://www.jkssh.or.kr/journal/view.html?uid=94\&page=\&pn=mostread\&sort=publish_Dat e\%20DESC\&spage=\&vmd=Full.

Kahn, L. B. (2010). The long-term labor market consequences of graduating from college in a bad economy. Labour Economics, 17(2), 303-316. doi.org/10.1016/j.labeco.2009.09.002.

Lam, M., \& Santos, A. (2018). The impact of a college career intervention program on career decision self-efficacy, career indecision, and decision-making difficulties. Journal of Career Assessment, 26(3), 425-444. https://doi.org/10.1177/1069072717714539.

Lent, R. W., Brown, S. D., \& Hackett, G. (1994. Toward a unifying social cognitive theory of career, and academic interest, choice, and performance. Journal of Vocational Behavior, 45, 79-122.

Lent, R. W., Brown, S. D., Sheu, H., Schmidt, J., Brenner, B. R., Gloster, C. S., \& Treistman, D. (2005). Social cognitive predictors of academic interests and goals in engineering: Utility for women and students at historically Black universities. Journal of Counseling Psychology, 52, 84-92.

Miles, J., \& Naidoo, A. V. (2017). The impact of a career intervention programme on South African Grade 11 learners' career decision-making self-efficacy. South African Journal of Psychology, 47(2), 209-221. https://doi.org/10.1177/0081246316654804.

Pambudi, A. T., Mulawarman, M., \& Japar, M. (2019). Psychoeducational Group with Modelling Technique to Improve Career Adaptability Through Career Decision Selfefficacy. Jurnal Bimbingan Konseling, 8(1), 20-31. https://doi.org/10.15294 /jubkv8i1.26617.

Park, I. J., Rie, J., Kim, H. S., \& Park, J. (2020). Effects of a future time perspective-based career intervention on career decisions. Journal of Career Development, 47(1), 96-110. https://doi.org/10.1177/0894845318781043.

Prideaux, L. A., \& Creed, P. A. (2001). Career maturity, career decision-making self-efficacy, and career indecision: A review of the accrued evidence. Australian Journal of Career Development, 10(3), 7-12. https://doi.org/10.1177/103841620101000303.

Rochat, S., \& Armengol, J. (2020). Career Counseling Interventions for Video Game Players. Journal of Career Development, 47(2), 207219. https://doi.org/10.1177/0894845318793537.

Salim, R., M., A., \& Darmayanti, K., K., H., D. n.d. After Earthquake in Sigi Regency, Can Social Support Enhance Secondary School Students' Career Decision Self-Efficacy.

Savickas, M. L. (2002). Career construction: A developmental theory of vocational behavior. In D. Brown \& Associates (Eds.), Career choice and development (4th ed., pp. 149205). San Francisco: Jossey Bass.

Savickas, M. L. (2005). The theory and practice of career construction. In S. D. Brown \& R. W. Lent (Eds.), Career development and counseling: Putting theory and research to work (42-70). New Jersey: John Wiley \& Sons, Inc.

Shin, Y. J., Lee, E. S., \& Seo, Y. (2019). Does Traditional Stereotyping of Career as Male Affect College Women's, but Not College Men's, Career Decision Self-Efficacy and Ultimately Their Career Adaptability? Sex Roles, 81(1-2), 74-86. https://doi.org/10.1007/s11199-018-0976-7. 
Super, D. E. (1951). Vocational adjustment: Implementing a self-concept. Occupations, 30, 88-92.

Super, D. E. (1980). A life span, life-space approach to career development. Journal of vocational behavior, 16(3), 282-298.

Super, D. E. (1990). A life span, life-space approach to career development. In D. Brown, L. Brooks, \& Associates (Eds.), Career choice and development (2nd ed., pp. 197-261). San Francisco: Jossey-Bass.

Taylor, K., M., \& Betz, N. E. (1983a). Applications of self-efficacy theory to the understanding and treatment of career indecision. Journal of Vocational Behavior, 22(1), 63-81. https://doi.org/10.1016/0001-8791(83)90006-4.

Tolentino, L. R., Garcia, P. R. J. M., Lu, V. N., Restubog, S. L. D., Bordia, P., \& Plewa, C. (2014). Career adaptation: The relation of adaptability to goal orientation, proactive personality, and career optimism. Journal of Vocational Behavior, 84(1), 39-48.

Vogelmeier, C. F., Criner, G. J., Martinez, F. J., Anzueto, A., Barnes, P. J., Bourbeau, J., ... \& Frith, P. (2017). Global strategy for the diagnosis, management, and prevention of chronic obstructive lung disease 2017 report. GOLD executive summary. American journal of respiratory and critical care medicine, 195(5), 557-582. https://doi.org/10.1164/rccm.201701-0218PP.

Wang, J. L., Zhang, D. J., \& Shao, J. J. (2010). Group training on the improvement of college students' career decision-making self-efficacy. Health, 2(06), 551. doi:10.4236/health.2010.26082. 